\title{
Effectiveness of Structured Teaching Program on Vitamin- A deficiency among the mother's of under-five children.
}

\author{
JitendraKhatri, \\ Principal, Mai Khadija Institute of Nursing Sciences, Jodhpur
}

\begin{abstract}
The objectives of the study were to assess the knowledge of mothers of under five children regarding vitamin- A deficiency, implement STP on vitamin- A deficiency and to analyze the effectiveness of STP before and after administration. An evaluative research approach with one group pre test post design was adopted for the study sample. 50 mothers of under-five children were selected by purposive sampling technique from ward No. 13 (Mangalwarpet), urban slum area of Raichur. Tool consists of section-A and section-B, It has 26 items in multiple choice questions and the total numbers of possible correct response were 45. The procedure has two phases, in first phase assessing the knowledge of mothers, after assessing the knowledge the STP was administered and in the second phase data were collected in order to test STP. The result revealed that pre test level of knowledge- $90 \%$ of subjects were having inadequate knowledge followed by moderate knowledge 6\% and adequate knowledge 4\%. After administering STP comparison of pre-test and post- test scores showed that there is statistical significant increase in post test knowledge score, (Pre test Mean 23.42, SD 8.3429, $t=$ 10.2788. Significant at $P \leq 0.01$.)
\end{abstract}

\section{Introduction}

A human life is divided in to five main stages mainly namely infancy, childhood, adolescence, adulthood, and old age. Among this early childhood is considered as one of the most important stage of life.

Children are nature's gift and fountains of life. Today's children are tomorrow's future. As they are our future and are supremely important asset of nation. The nurture and solicitude are our responsibility. Therefore the health status of children in considered as an index of nation development.

During early childhood development period they require adequate nutrients, if they are not full filled with this nutrient requirement, they suffer from certain deficiency disorders, vitamin- A deficiency disorder is one of them.

The right to see is one of the important aspects, out of the five senses man possesses, vision is the most important. Therefore it is important that proper care should be taken to safeguard the precious gift of god. Prolonged vitamin- A deficiency can lead to night blindness in children. Clinically eye signs of vitamin- A deficiency i.e Bitot's spots, Corneal Xerosis, Keratomalacia and Corneal scars are well established indicators of severe vitamin- A deficiency.

It is considered as Public Health Problem in India, It is responsible for $0.3 \%$ of total cause of blindness in the country. It is the second most important factor of global blindness. Every year 250,000 to 500,000 children become blind partially or totally due to vitamin- A deficiency.

Vitamin- A deficiency- cause of child death can be prevented. In recent years new scientific studies have shown that ensuring children have enough vitamin-A can increase their chance of survival about $23 \%$.

The vitamin- A deficiency in the under five can be prevented easily by increasing consumption of vitamin A rich food, breast feeding to children, proper immunization of children and decreased contributory condition like PEM, RTI, diarrhoea, measles at community level as well as providing education regarding necessity of vitamin- A, sources and deficiencies to mothers of under five children.

Objectives

1. To assess the knowledge of mothers of under five children regarding vitamin- A deficiency.

2. To implement STP on Vitamin- A deficiency.

3. To analyze the effectiveness of STP on knowledge regarding vitamin- A deficiency among mothers of under five children.

4. To find association between the demographic variable and knowledge regarding vitamin- A among the mothers of under five children.

\section{Methodology}

Sample-Total 50 mothers' of under five children were selected by purposive sampling technique from ward no 13 (Mangalwaret), urban slum area of Raichur. The research design selected for this study was one group pretest post- test design. 
Measures-The tool consist of section A- Socio- demographic data and section B- Structured questionnaire, it has 26 items in multiple choice question format. Each question had one or more possible correct responses and each possible correct response by mother's of under five children was awarded one score point. The total numbers of possible correct responses were 45 .

The score keys of mother's under five children were categorized on the basis of their level of knowledge as inadequate level of knowledge 0.22 (0-50\%), moderate level of knowledge 22-33 (51-75\%), \& adequate level of knowledge $>33(>75 \%)$ respectively.

Content validity was obtained from twelve experts in the field of pediatric nursing. Based upon their valuable suggestions and recommendations the tool has been modified.

Procedure- Formal permission was obtained from the higher authorities and researcher explained about self and the purpose of study. In the first phase knowledge of mothers of under-five children regarding vitamin- A deficiency was assessed. After assessing the knowledge the structured teaching programme was administered and in the second phase data were collected in order to test the effectiveness of structured teaching program on vitamin- A deficiency.

III. Result-

Table 1:Percentage Distribution of sample by demographic variables

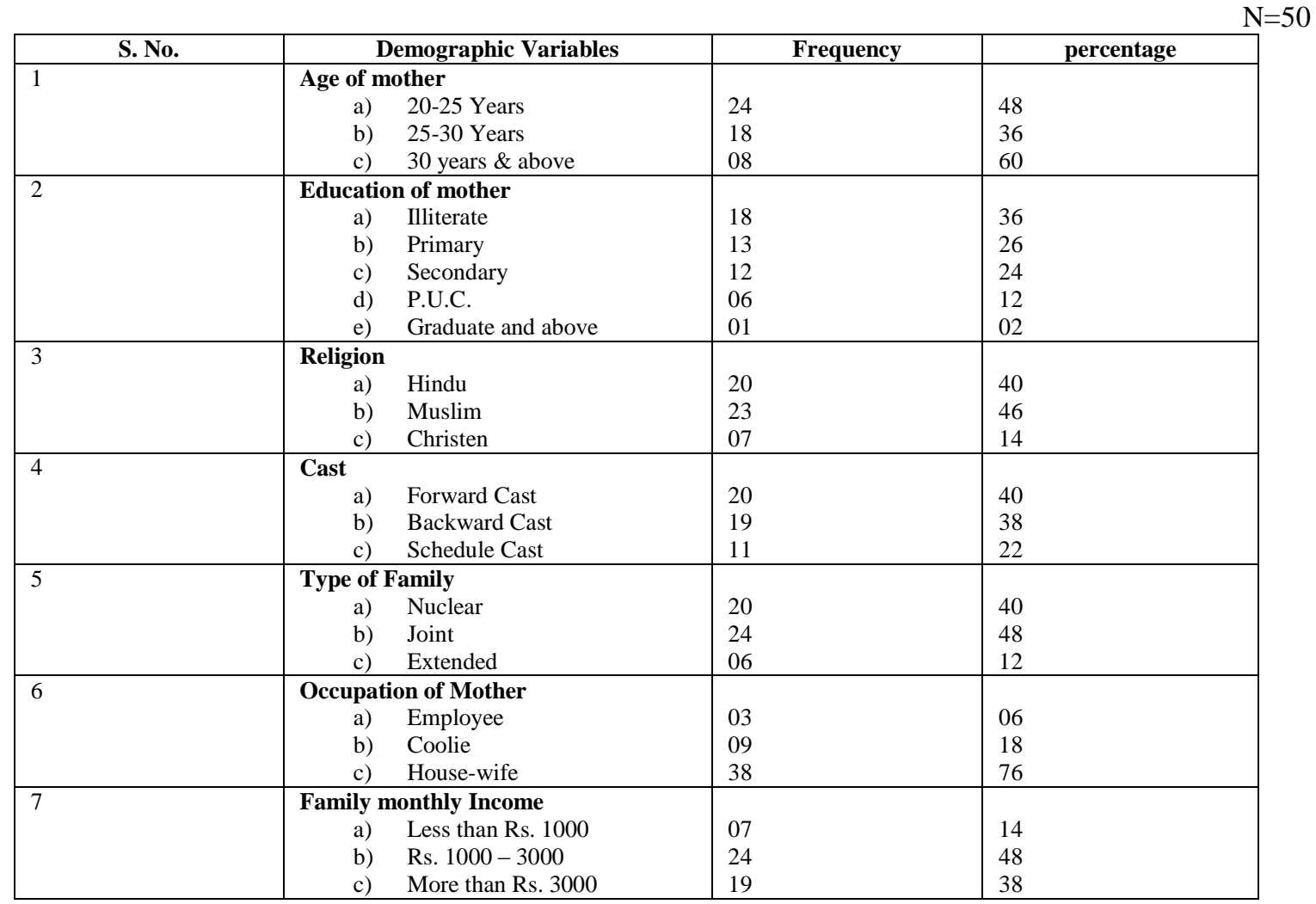

Fig 1.Pre-test level of knowledge

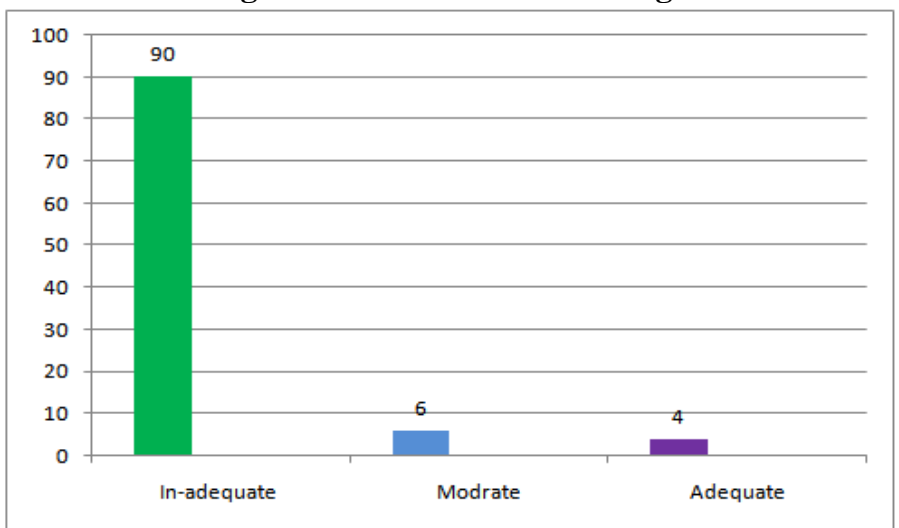

Fig. 1 Percentage distribution according to level of knowledge in Pre-test 
Fig.1 Reveals the pre-test level of knowledge $90 \%$ of subject were having inadequate knowledge followed by moderate knowledge $6 \%$ and adequate knowledge $4 \%$.

Table 2:Comparison of pre-test and post-test scores.

\begin{tabular}{|c|l|l|l|l|l|l|}
\hline \multirow{2}{*}{ S. No. } & \multicolumn{3}{|c|}{ Pre-Test } & \multicolumn{2}{c|}{ Post- Test } & \multirow{2}{*}{ t } \\
\cline { 2 - 5 } & Mean & SD & Mean & SD & Value & \\
\hline 1. & 14.72 & 6.47 & 23.42 & 8.3429 & 10.2788 & S** \\
\hline
\end{tabular}

$\mathrm{S}^{* *}=\quad$ Significant $\mathrm{t}$, df $(49)=10.2788$, at $\mathrm{P} \leq 0.01$

Table 2:Shows that there is statistical significant increase in post test knowledge score from the pre-test.

Chi-square Table Showing Association of Post Test Knowledge Scores of Mother of Under Five Children \&Related Factors.

\begin{tabular}{|c|c|c|c|c|c|c|c|c|}
\hline \multirow{2}{*}{$\begin{array}{l}\text { S. } \\
\text { No. }\end{array}$} & \multirow{2}{*}{ Selected Factor } & \multicolumn{3}{|c|}{ Knowledge Score } & \multirow{2}{*}{$\begin{array}{c}\text { Chi } \\
\text { Square }\end{array}$} & \multirow{2}{*}{$\begin{array}{c}\text { Table } \\
\text { Nale }\end{array}$} & \multirow{2}{*}{ df } & \multirow{2}{*}{$\begin{array}{c}\text { S/NS at } 0.05 \\
\text { level of } \\
\text { significance }\end{array}$} \\
\hline & & Inadequate & Moderate & Adequate & & & & \\
\hline $\begin{array}{l}1 . \\
2 . \\
3 .\end{array}$ & $\begin{array}{l}\text { Age of Mother } \\
20-25 \\
25-30 \\
30 \& \text { Above }\end{array}$ & $\begin{array}{l}7 \\
7 \\
4\end{array}$ & $\begin{array}{l}15 \\
6 \\
3 \\
\end{array}$ & $\begin{array}{l}2 \\
5 \\
1\end{array}$ & $5.33 \mathrm{H}$ & 13.28 & 4 & NS \\
\hline $\begin{array}{l}1 \\
2 \\
3 \\
4 \\
5\end{array}$ & $\begin{array}{l}\text { Education of } \\
\text { Mother } \\
\text { Illiterate } \\
\text { Primary } \\
\text { Secondary } \\
\text { PUC } \\
\text { Graduate \& Above }\end{array}$ & $\begin{array}{l}12 \\
3 \\
2 \\
1 \\
-\end{array}$ & $\begin{array}{l}16 \\
9 \\
7 \\
2 \\
-\end{array}$ & $\begin{array}{l}- \\
1 \\
3 \\
3 \\
1\end{array}$ & 23.372 & 20.09 & 8 & S \\
\hline $\begin{array}{l}1 \\
2 \\
3\end{array}$ & $\begin{array}{l}\text { Religion } \\
\text { Hindu } \\
\text { Muslim } \\
\text { Christen }\end{array}$ & $\begin{array}{l}6 \\
11 \\
01\end{array}$ & $\begin{array}{l}12 \\
9 \\
3\end{array}$ & $\begin{array}{l}2 \\
3 \\
3\end{array}$ & 6.757 & 13.28 & 4 & NS \\
\hline $\begin{array}{l}1 \\
2 \\
3 \\
4\end{array}$ & $\begin{array}{l}\text { Occupation of } \\
\text { Mother } \\
\text { Employee } \\
\text { Collie } \\
\text { Hw } \\
\text { Business }\end{array}$ & $\begin{array}{l}- \\
4 \\
14 \\
-\end{array}$ & $\begin{array}{l}- \\
4 \\
20 \\
-\end{array}$ & $\begin{array}{l}3 \\
1 \\
4 \\
-\end{array}$ & 16.976 & 13.28 & 4 & S \\
\hline $\begin{array}{l}1 \\
2 \\
3\end{array}$ & $\begin{array}{l}\text { Family Monthly } \\
\text { Income } \\
\text { Less } 1000 \\
1000-3000 \\
>3000\end{array}$ & $\begin{array}{l}5 \\
8 \\
5\end{array}$ & $\begin{array}{l}1 \\
14 \\
09\end{array}$ & $\begin{array}{l}1 \\
2 \\
05\end{array}$ & 7.334 & 13.28 & 4 & NS \\
\hline $\begin{array}{l}1 \\
2 \\
3\end{array}$ & $\begin{array}{l}\text { Type of Family } \\
\text { Nuclear } \\
\text { Joint } \\
\text { Extended }\end{array}$ & $\begin{array}{l}5 \\
9 \\
3\end{array}$ & $\begin{array}{l}11 \\
12 \\
2\end{array}$ & $\begin{array}{l}04 \\
03 \\
1\end{array}$ & 1.833 & 13.28 & 4 & NS \\
\hline
\end{tabular}

\section{Discussion}

Objective 1:To assess the knowledge of mother of under five children regarding vitamin- A- deficiency.

Study findings revealed that in Pre-test $90 \%$ of subject were having inadequate knowledge followed by moderate knowledge $6 \%$ and adequate $4 \%$.

Objective 2:To analyse the effectiveness of STP on knowledge regarding vitamin- A deficiency among mothers of under five children.

Study finding revealed that the mean of the Pre-test 14.72, Post-test mean 23.42, the calculated ' $t$ ' value 10.2788 which is greater than table value at $\mathrm{P} \leq 0.01$ level of significance. Hence research hypothesis was accepted.

Objective 3:To find association between the demographic variable and knowledge regarding vitamin- A among the mothers of under five children.

In order to determine the significant association of Pre-test knowledge level with selected sociodemographic variable, chi-square test was used. There is no statistically significant association was found between socio-demographic variable except education of mother, occupation of mother. 


\section{For Nursing Education}

\section{Implication}

- The nurse educators could emphasize on health education of Vitamin- A deficiency and its prevention as a part of learning experience for the students.

- Student could be encouraged to indentify the sign and symptoms of Vitamin- A deficiency, by educating the mother's of under five children

- The Nurse educator can arrange for the in-service education program for nurses regarding Vitamin-A deficiency and its prevention.

- The Nurse educator can provide an opportunity for students to actively participate in implementation of national prophylactic programme.

For Nursing Practice

- Nurses should be equipped with updated knowledge on prevention of Vitamin-A deficiency so that they would be able to impart appropriate knowledge to community.

- Since nurses are the first source of knowledge for the mothers, they are to the more patient oriented and educate mothers about Vitamin-A deficiency and its prevention .

- Nurses would be able to organize the health education program for the community about the importance of Vitamin-A and the measures to prevent its deficiency among children of age group 0-5 years.

- With the knowledge of Vitamin-A, the nurse would be able to prevent its deficiency for becoming completed and make the children have good eyesight.

\section{For Nursing Research}

- The study will be a motivating for budding researchers to conduct similar studies on a large scale.

- The study will be reference for the research scholars.

- More researches can be conducted by researchers using experimental study.

\section{Conclusion}

Children are flowers of garden, taking care of flowers is the responsibility of the guardians, as said prevention is better than cure, mothers of under five should have adequate knowledge regarding prevention of Vitamin- A deficiency, as well as sources to nurture the children in proper way. STP was effective \& improved knowledge of mother's of under-five children.

\section{Bibliography}

[1]. BLINDNESS: THE GLOBAL PICTURE, 1993: W.H.O Fact Sheet. No. 213

[2]. CONTROL OF VITAMIN-A DEFICIENCY AND XEROPHTHALMIA, 1982L W.H.O. Technical. Report. Series. No. 972.

[3]. Dwivedi, S. Et Al. 1995: ' Medico-social factors affecting Vitamin-A deficiency among children" HEALTH AND POPULATIONPERSPECTIVE AND ISSUE, Val. 18(1), P. No. 27-36.

[4]. ENDING HIDDEN HUNGER, 1992: WHO/UNICEF Conference and world summit for children, Bellagio, Italy.

[5]. Kulkarni, M.L. 2001: ' Prevalence of Vitamin-A deficiency in central Karnataka (India) and role of conjunctival impression cytology in detecting Vitamin-A Deficiency". NEWSLETTER- SIGHT AND LIFE. P. NO. 31

[6]. Ministry of Health and family welfare, 1991: "POLICY ON Management OF VITAMIN-A DEFICIENCY". Government of India.

[7]. PREVAlENCE CRITERIA FOR DETERMINING THE XEROPHTHALMIA, 1982: W.H.O. Technical, Report. Series; General No. 672.

[8]. STRATEGIES TO CONTROL MICRONUTRIENT MALNUTRITION, 1994: IMCR Bulletin, New Delhi Vol. $24(8)$ P. NO. 79-84.

[9]. VITAMIN -A DEFICIENCY AND XEROPHTHALMIA, 1982. W.H.O. Technical Report. Series. No. 672.

[10]. Women and child development department, 1995:"STRATEGY FOR ELIMINATION OF MICRONUTRIENT MALNUTRITION IN INDIA". W and C.D. Department, Government of India. 